sure. In a liberal polity, one wishes to assure trial procedures that are as generous as possible, even amid the exigencies of a very real conflict.

Still, the problems of a different kind of war remain, especially for any trials that are convened in the middle of the battle. Some $\mathrm{Al}$ Qaeda actors may simply be held for the duration of an arduous conflict, as combatants captured in war, subject to administrative safeguards. Should criminal trials be held, we may wish to acknowledge that our familiar habits from civilian courts and United Nations tribunals are not the only models of fairness. The humanitarian law of war and the law of armed conflict are equally a part of international law, framed to meet the unsought circumstances of states that must protect the safety of their citizens.

RLTH WEDGWOOD*

\title{
The Case Against Military COMmissions
}

In January 2002, Zacarias Moussaoui, a French national of Moroccan descent, pleaded not guilty in Virginia federal court to six counts of conspiring to commit acts of international terrorism in connection with the September 11 attacks on the Pentagon and the World Trade Center. ${ }^{1}$ In other times, it would have seemed unremarkable for someone charged with conspiring to murder American citizens and destroy American property on American soil to be tried in a U.S. civilian court. More than two centuries ago, Article I, Section 8, Clause 10 of the United States Constitution granted Congress the power to "define and punish Piracies, Felonies committed on the High Seas, and Offenses against the Law of Nations," a power that Congress immediately exercised by criminalizing piracy, the eighteenth-century version of modern terrorism. ${ }^{2}$ Since then, Congress has criminalized numerous other international offenses. ${ }^{3}$ In recent decades, United States courts have decided criminal cases convicting international hijackers, terrorists, and drug smugglers, ${ }^{4}$ as well as a string of well-publicized civil lawsuits adjudicating gross human rights violations. ${ }^{5}$ Most pertinent, federal prosecutors have successfully tried and convicted in U.S. courts numerous members of Al Qaeda, the very terrorist group charged with planning the September 11 attacks, for earlier attacks on the World Trade Center and the U.S. embassies in Tanzania and Kenya. ${ }^{6}$

Had only three or three hundred died on September 11, no one would have suggested that their murderers be tried anywhere but in U.S. civilian courts. This history made even more surprising President Bush's military order (Military Order), issued on November 13, 2001, with-

\footnotetext{
- Of the Board of Editors.

${ }^{1}$ Brooke A. Masters, Invoking Allah, Terror Suspect Enters No Plea: U.S. Judge in Alexandria Schedules October Trial, WASH. POST, Jan. 3, 2002, at Al.

${ }^{2}$ Act of Apr. 30, 1790, ch. 9, §8, 1 Stat. 112, 113-14.

${ }^{3}$ See, e.g., 18 U.S.C. $\$ 1201$ (aircraft sabotage and kidnapping act), $\$ 1203$ (criminalizing hostage taking), $\$ 831$ (theft of nuclear materials) (2000).

${ }^{4}$ See, e.g., United States v. McVeigh, 9 Fed. Appx. 980 (10th Cir. 2001), 2001 U.S. App. LExIS 11804 (unpublished); United States v. Noriega, 683 F.Supp. 1373 (S.D. Fla. 1988) (trying Panamanian leader who was apprehended by U.S. Special Forces after extended military operations).

${ }^{5}$ See, e.g., Kadic v. Karadzic, 70 F.3d 232, 238 (2d Cir. 1995), cert. denied, 518 U.S. 1005 (1996); In re Estate of Marcos, 25 F.3d 1467, 1472-76 (9th Cir. 1994), cert. denied, 513 U.S. 1126 (1995); Filartiga v. Pena-Irala, 630 F.2d 876 (2d Cir. 1980). See generally Harold Hongju Koh, Transnational Public Law Litigation, 100 YALE L.J. 2347 (1991) (reviewing litigation trend).

${ }^{6}$ See Charisse Jones, Four Guilty in U.S. Embassy Attacks: Two Bombings in Africa Killed 224, USA TODAY, Mav 30 , 2001, at 1A; Martha T. Moore, Bomb Verdicts Are 2nd Victory for Government, USA TODAY, Nov, 13, 1997, at 3A. Linder the Classified Information Procedures Act, U.S. prosecutors have regularly used special pretrial procedures in these cases to protect classified information. 18 U.S.C. app. 696, \$1 (2000). See generally Richard P. Salgado, Govermment Secrets, Fair Trials, and the Classified Information Procedures Act, 98 YALE L.J. 427 (1988) (describing practice under the Act); Bill Keller, Trials and Tribulations, N.Y. TIMES, Dec. 15, 2001, at A31 ("Over the past eight vears the U.S. attorney [for the Southern District of New York] . . . has successfully prosecuted 26 jihad conspirators, in six major trials and some minor ones.").
} 
out congressional authorization or consultation, which cleclared that " $[\mathbf{t}]$ o protect the United States and its citizens, . . it is necessary for (noncitizen suspects designated by the president under the order). . . to be tried for violations of the laws of war and other applicable lawes by military tribunals." It came as no surprise, however, that the Military Order quickly attracted intense criticism from constitutional and international lawyers. ${ }^{8}$ That response has triggered a legal process of narrowing the order that seems likely to continue until the first commission cases are brought. ${ }^{9}$

Nevertheless, the practical question remains: given the exigencies created by the events of September 11, why should the United States not have the option of trying suspected terrorists before military commissions? Two simple answers: First, the Military Order undermines the United States' perceived commitment to the rule of law and national confidence in U.S. judicial institutions at precisely the time when that commitment and confidence are most needed. Second, by failing to deliver justice that the world at large will find credible, the Military Order undermines the U.S. ability to lead an international campaign against terrorism under a rule-of-law banner.

\section{How COMMISSIONS FAIL}

\section{Undermining the Rule of Law}

The Military Order's specific legal deficiencies have received extensive commentary and are cogently summarized in a recent letter to the chair of the Senate Committee on the Judiciary signed by more than seven hundred American law professors. ${ }^{10} \mathrm{On}$ its face, the order at1thorizes the Department of Defense to dispense with the basic procedural guarantees required by the Bill of Rights, the International Covenant on Civil and Political Rights (ICCPR), and the

\footnotetext{
'Military Order, Detention, Treatment, and Trial of Certain Non-Citizens in the War Against Terrorism $\$ 1$ (e) (Nov. 13, 2001), 66 Fed. Reg. 57,833 (Nov. 16, 2001) [hereinafter Military Order] (emphasis added). The Military Order provides: (1) that "it is not practicable to apply in military commissions under this order the principles of law and the rules of evidence generally recognized in the trial of criminal cases in the United States district courts"; (2) that trials need not be open: (3) that conviction and sentencing shall be "only upon the concurrence of twothirds of the members of the commission"; and (4) that defendants "shall not be privileged to seek any remedy or maintain any proceeding, directly or indirectly," in any U.S., foreign, or international court. Id. $\$ \$ 1(\mathrm{f}), 4(\mathrm{c})(4)$, $4(\mathrm{c})(6)-(7), 7(\mathrm{~b})(2)$.

${ }^{8}$ See George Lardner, Jr., On Left and Right, Concerm Over Anti-Terrorism Moves: Administration Actions Threnten Civil Liberties, Critics Say, WASH. POST, Nov. 16,2001, at A40.

"The president's legal counsel subsequently asserted that the order "covers only foreign enemy war criminals" who are chargeable "with offenses against the international laws of war"; that the order "does not require that any trial, or even portions of a trial, be conducted in secret"; that "[e]veryone tried before a military commission will know the charges against him, be represented by qualified counsel and be allowed to present a clefense"; and that "anyone arrested, detained or tried in the United States by a military commission will be able to challenge the lawfulness of the commission's jurisdiction through a habeas corpus proceeding in a federal court." Alberto $R$. Conzales, Martial Justice, Full and Fair, N.Y. TIMEs, Nov. 30, 2001, at A27. While the regulations issued by the Department of Defense after this essay was written (U.S. Dep't of Defense, Military Commissions Order No. 1, Procedures for Trials by Military Commissions of Certain Non-United States Citizens in the War Against Terrorism (Mar.21,2002), at<http://www.defenselink.mil/news/Mar2002/d2002032 lord.pdf $>$ ) respond to the heated criticism of the Military Order by providing more courtlike guarantees, they pointedly omit any opportunity for judicial review before a civilian court. The irony, as I suggest in the text, is that procecdings before these commissions will now be likely to suffer from many of the inefficiencies associated with judicial proceedings, but without garnering in return the global respect that genuine, credible judicial proceedings are accorded.

${ }^{10}$ Letter from Law Professors and Lawyers to the Honorable Patrick J. Leahy (Dec. 5, 2001), $a t<$ http://uww.yale.edu/ lanweb/liman/letterleahy,pdt $>$ [hereinafter Law Professors' Letter]. Those law professors (including this audhor) called "the untested institutions contemplated by the Order . . legally deficient, unnecessary, and unwise." In particular, they argued that the order violates separation of powers, "dues not comport with either constitutional or international standards of due process," and "allows the Executive to violate the United States' binding treaty obligations." For devastating critiques of the Military Order under American constitutional law, sec, for example, Neal K. Katyal \& Laurence H. Tribe, Waging War, Deciding Guilt: Tiying the Military Tribunals, 111 YALE L.J. 1259 (2002) (arguing that order is unconstitutional on its face); George P. Fletcher, War and the Constinution: Bush's Militany Tribunals Haven't Got a Legal Leg to Stand On, AN. PrOsPlECT, Jan. 1-14, 2002, at 26.
} 
Third Geneva Convention of 1949." Insofar as any of these guarantees-which include the presumption of innocence, the rights to be informed of charges and to equal treatment before the courts, public hearings, independent and impartial decision makers, the rights to speedy trial, confrontation, and counsel of one's own choosing, the privilege against self incrimination, and review by a higher tribunal according to law-are subject to suspension in time of emergency, the Bush administration has taken no formal steps to enable it to derogate from them. ${ }^{12}$ By omitting these guarantees, the Military Order violates binding U.S. treaty commitments under both the ICC.PR and the Third Geneva Convention. ${ }^{13}$

Fundamentally, the Military Order undermines the constitutional principle of separation of powers. For under the order, the president directs his subordinates to create military commissions, to determine who shall be tried before them, and to choose the finders of fact, law, and guilt. However detailed its rules and procedures may be, a military commission is not an independent court, and its commissioners are not genuinely independent decision makers. Historically, a military commission is neither a court nor a tribunal, but "an advisory board of officers, convened for the purpose of informing the conscience of the commanding officer, in cases where he might act for himself if he chose." Commissioners are not independent judges, but usually military officers who are ultimately answerable to the secretary of defense and the president, who prosecute the cases. "Such blending of functions in one branch of the Government," Justice Black recognized, "is the objectionable thing which the draftsmen of the Constitution endeavored to prevent by providing for the separation of governmental powers."

Admittedly, in Ex parte Quirin, a pressured Supreme Court upheld the use of World War II military commissions, reasoning that Nazi saboteurs who had entered the United States

" U.S. CONST. amends. V, VI, VIII; International Covenant on Civil and Political Rights, Dec. 16, 1966, Art. 14, 999 UNTS 171 [hereinafter ICC.PR]; Convention Relative to the Treatment of Prisoners of War, Aug, 12, 1949, Arts. 4-5, 6 UST 3316, 75 UNTS 135 [hereinafter Third Geneva Convention]; see also Joan Fitzpatrick, Jurisdiction of Military Commissions and the Ambiguous War on Terrorism, 96 AJIL 345 (2002); Dary. A. Mundis. The Use of Military Commissions to Proserute Individucts Accused of Terrorist Acts, 96 AJIL 320 (2002) (both finding inconsistencies between administration's position and international standards).

${ }^{12}$ See Ex parte Milligan, 71 U.S. (4 Wall.) 2, 120-21 (1866) (stating that the U.S. Constitution is a "law for rulers and people, equally in war and in peace, ... at all times, and under all circumstances. No doctrine, involving more pernicious consequences, was ever invented by the wit of man than that any of its provisions can be suspended during any of the great exigencies of government."). In any event, the Bush administration has taken none of the requisite steps to declare a state of emergency warranting derogation from its ICC.PR obligations. See also The Administration of Justice and the Human Rights of Detainees: Question of Human Rights and States of Emergency, UN Doc. E/CN.4/Sub.2/1997/19, para. 111 (1997) ("[M] easures adopted by a Government to combat terrorism should not affect the exercise of the fundamental rights set forth in the Covenant ... Regarding article 14 [fair trial requirements], the [Human Rights] Committee said that no derogation whatsoever from any of its provisions was possible.").

${ }^{13}$ Law Professors' Letter, supra note 10 (stating that the ICC.PR "obligates States Parties to protect the due process rights of all persons subject to any criminal proceeding" and that the Third Geneva Convention "requires that every prisoner of war have a meaningful right to appeal a sentence or a conviction. L'nder Article VI of the Constitution, these obligations are the 'supreme Law of the Land' and cannot be superseded by a unilateral presidential order.").

${ }^{14}$ Milligan, 71 U.S. at 47 (quoting David Dudley Field's Supreme Court argument). Military commissioners are even less independent than court-martial judges, who operate under the statutory protections of the Uniform Code of Military Justice. Yet as Justice Black noted in Reid v. Covert, 354 U.S. 1, 36 (1957) (plurality opinion), even "[c] onceding to military personnel that high degree of honesty and sense of justice which nearly all of them undoubtedly have, the members of a court-martial, in the nature of things, do not and cannot have the independence of jurors drawn from the general public or of civilian judges."

${ }^{15}$ Even when sitting American judges have seıved on military commissions, their independence has been compromised because they act as appointees of the executive branch capable of being fired or ordered to decide particular cases in particular ways. See RoberT M. Cover, OWEN M. FISS, \& J L'dITH Res.Nik, Procedire 1343-45 (1988) (describing "United States Court for Berlin," an "Article II court" established in 1979 under authority of the U.S. high commissioner for Germany and presided over by Herbert Stern, a sitting Article III judge: "After that suit was filed in Berlin, the United States Ambassador ... instructed the judge on how he was to decide the case; the ambassador ordered Judge Stern either to dismiss the case or to resign his commission.").

"Reid, 354 U.S. at 39 . 
clandestinely were "unlawful belligerents," having forfeited their prisoner-of-war status by removing their uniforms, surreptitiously entering the United States, and committing acts of sabotage. ${ }^{17}$ But Quirin nowhere gave the president carte blanche unilaterally to create an alternative military system of criminal justice for suspicious aliens captured abroad. ${ }^{18}$ Nor did Quirin authorize the president unilaterally to shift all cases involving war crimes by detained noncitizens into military commissions. ${ }^{19}$ In Quirin, Congress had formally declared war, which it has not done here, and had specifically authorized the use of military commissions in its Articles of War. ${ }^{2 n}$ In any event, it seriously disserves the long-term interests of the United States-whose nonuniformed intelligence and military personnel will conduct extensive armed activities abroad in the months ahead-to assert that any captive who can be labeled an "unlawful combatant" should be denied prisoner-of-war status under the Geneva Conventions, and hence subjected to trial for "war crimes" before military commissions."1

These specific legal deficiencies stand atop a much broader rule-of-law concern. International law permits the United States to redress the unprovoked killing of thousands on September 11, 2001, by itself engaging in an armed attack upon the Al Qaeda perpetrators. But should those culprits be captured, the United States must try, not lynch, them to promote four legal values higher than vengeance: holding them accountable for their crimes against humanity; telling the world the truth about those crimes; reaffirming that such acts violate all norms of civilized society; and demonstrating that law-abiding societies, unlike

is 317 U.S. 1 (1942). Quirin was itself an embarrassing "tale of" . . a prosecution designed to obtain the death penalty; ... a rush to judgment, [and] an agonizing effort to justify a fait accompli." David J. Danelski, The Sabotears' Case, 1 J. S.CT. HIST. 61,61 (1996). Justice Douglas later recalled the procedure in Quirin, which announced a result with an opinion following later, as "extremely undesirable"; Justice Frankfurter, as "not a happy precedent." Justice Black's law clerk argued that "if the judges are to run a court of law and not a butcher shop, the reasons for killing a man should be expressed before he is dead; otherwise the proceedings are purely military and not for courts at all." Id. at 80; accord Robert E. Cushman, Ex parte Quirin et al.-The Nazi Saboteur Case, 28 CORNELL L.Q. 54 (1942) (recounting rush to judgment).

${ }^{1 *}$ Fifteen years after Quirin, Justice Black reiterated that "[e]very extension of military jurisdiction," including, presumably, the assertion of military jurisdiction over alien war crimes, "is an encroachment on the jurisdiction of the civil courts, and, more important, acts as a deprivation of the right to jury trial and of other treasured constitutional protections." Reid, 354 U.S. at 21.

${ }^{199}$ Far from endorsing such a broad divestiture of civilian jurisdiction over war crimes, Congress in 1996 enacted the War Crimes Act, which plainly envisioned that persons inside or outside the United States who commit certain statutory "war crimes" should be punished before the extant, functioning U.S. courts. War Crimes Act, 18 U.S.C. \$2441 (2000); accord Reid, 354 U.S. at 41 (Frankfurter, J., concurring in the result) ("The normal method of trial of federal offenses under the Constitution is in a civilian tribunal. Trial of offenses by way of court-martial, with all the characteristics of its procedure so different from the forms and safeguards of procedure in the conventional courts, is an exercise of exceptional jurisdiction ..." ).

2" Quirin carefully specified that "[i]t is unnecessary for present purposes to determine to what extent the President as Commander in Chief has constitutional power to create military commissions without the support of Congressional legislation." 317 U.S. at 29 (emphasis added). The Act of Congress passed immediately after September 11 does not authorize the adjudication by military commissions of past acts by apprehended terrorists. It only authorizes the president to use "force" against persons involved in the September 11 attacks so as to prevent future harm to the United States. Authorization for Use of Military Force, Pub. L. No. 107-40, 115 Stat. 224 (2001).

${ }^{21}$ Accord William Glaberson, Crilics' Allack on Tribunals Furns to Law Among Nations, N.Y. TIMES, Dec. 26, 2001, at B1 (citing international lawyers who argue that Military Order conflicts with the Geneva Conventions' guarantees of procedural rights to prisoners of war). Significantly, the first two reported American casualties in Afghanistan were a nonuniformed CIA agent killed at a prison riot and a Special Forces officer ambushed while investigating civilian deaths. John Diamond \& L.iz Sly, Enemy A mbush Kills U.S. Soldier; Sumender Talks Continue near Omar's Hideout, CHICACO TRIB., Jan. 5, 2002, at 1, available in LEXIS, News Library, Majpap File. Under the broad definition now asserted by the Bush administration, both deceased Americans could have been labeled "unlawful combatants" potentially triable before military tribunals. This concern makes even more troubling the White House's recent, blanket determination that although the Geneva Conventions apply to Taliban detainces (but not $\mathrm{Al}$ Qaeda), anyone who fought for the Taliban violated the laws of war and thus cannot claim prisoner-of-war status. White House Fact Shect, Status of Detainces at Guantanamo (Feb. 7, 2002), at <http://www.whitehouse.gov/news/ releases/2002/02>. A correct application of the Geneva Conventions would have required that all detainee's in U.S. custody be presumed to be prisoners of war until each had his status individually determined by the "competent tribunal" required by Article 5 of the Third Geneva Convention, supra note 11 . Thus, the president's announced decision to apply the Geneva Conventions to Taliban detainees should have required him to defer to a competent tribunal's individualized determinations as to whether particular detainees are entitled to prisoner-ofwar status, not allowed him to inake his own blanket determination that all detainces are per se unlawful combatants. 
terrorists, respert human rights by channeling retribution into criminal punishment for even the most heinous outlaws.

The Military Order undermines each of these values. First, military commissions create the impression of kangaroo courts, not legitimate mechanisms of accountabilitv. Second, rather than openly announcing the truth, commissions tend to hide the very facts and principles the United States now seeks to announce to the world. Third, because military tribunals in Burma, Colombia, Egypt, Peru, Turkey, and elsewhere have been perceived as granting judgments based on politics, not legal norms, the United States Department of State has regularly pressed to have cases involving U.S. citizens heard in civilian courts in those countries. ${ }^{22}$

Those who promote military commissions have been misled by the O.J. Simpson fiasco to conclude that standing American courts-whether civilian courts or military courts-martial-are somehow incapable of rendering full, fair, and expeditious justice in such cases. One might understand a country's resorting to a military commission when no currently functioning court could fairly and efficiently try the case. But over the centuries, the L.S.judicial system has amply demonstrated its ability to adapt to new, complex problems in criminal and civil law. Why should the United States try suspects in military commissions without congressional authorization when its own federal courts have fairly and openly tried and convicted Al Qaeda members? Perversely, the Military Order threatens national confidence in existing legal institutions and principles just when that confidence is al ready badly shaken by horrific terrorist attacks. Despite those attacks, both the presidency and Congress have continued to function, yet the order implicitly assumes that the third branch, comprising existing civilian and military courts, can no longer handle the very cases it dealt with just before the attacks occurred. ${ }^{2: 3}$

Fourth and finally, military commissions provide ad hoc justice, hence uncertain protection for defendants' rights. Although the Defense Department's regulations implementing the order reportedly provide greater protections for the accused, unlike the Bill of Rights, the Federal Rules of Criminal Procedure, or the Uniform Code of Military Justice, those regulations cannot guarantee those rights, as they are subject to change at the president's will. ${ }^{24}$ The absence of binding legal protection for the accused's human rights will become particularly acute should military commissions be convened at the Lnited States Naval Base at Guantánamo Bay, Cuba, where scores of the detainees have been transferred. ${ }^{25}$ In 1994, when large numbers of Cuban boat people were held on Guantánamo, the L.S. Court of Appeals for the Eleventh Circuit rendered the extraordinarily broad (and strongly contested) ruling that "these [alien detainees on Guantánamo] are without legal rights that are cognizable in

\footnotetext{
When Peru, for example, branded Lori Berenson, an American citizen, a "terrorist:" the Lnited States properly protested that her "trial" was not held in open civilian court with full rights of legal clefense, in accordance with international judicial noms. See U.S. DeP'T of STATE, Peru, in 1999 COL XTRI RfPorts O.N HL MLAN RIGHTS PRACTICES, available al <http://www.state.gov/uww/global/human_rights/1999_hrp_report/peru.html>.

${ }^{23}$ Attomey General John Ashcroft's own public defense of the Military Order before Congress was stumning in its dismissiveness about the capacity of United States judges and federal prosecutors (whose nominations he orersees) to try terrorist suspects fairly and expeditiously under existing judicial procedures. Ser Lane, supra note 10 (quoting testimony of Attorney General John Ashcroft, Senate Committee on the Judiciar, Dec. 6, 2001 (".Are we supposed to read [terror suspects] their Miranda rights, hire a flamboyant defense lawyer, bing them back to the Lnited States to create a new cable network of 'Osama TV,' provide a worldwide platiorm for propaganda:")).

${ }^{24}$ Cf. Ex parte Milligan, 71 U.S. (4 Wall.) 2, 119 (1866) ("By the protection of the law human rights are secured; withdraw that protection, and they are at the mercy of wicked rulers, or the clamor of an excited people."). Lnder the so-called Charming Betsy principle, U.S. courts have regularly restrained proposed executive action within the bounds of international legal obligations. Murray v. The Schooner Charming Betsy, 6 L.S. (2 Cranch) 64, 118 (1804) (Marshall, C.J.). See generally Ralph G. Steinhardt, The Role of International Lau a a Canon of Domestic Sialuton Construction, 43 VAND. L. REV. 1103 (1990). To the extent that both the Third Genera Convention and the ICCPR represent customary international law, fidelity to binding international obligations should require that the openended language of the Military Order be construed to require the procedural guarantees required by those instruments.

${ }^{25}$ Katharine Q. Seelye, Troops Amive at Base in Cuba to Build Jails, N.Y. TIMES, Jan. 7, 2002, at A8 (Defense Secretary "Rumsfeld said he had not ruled out holding such tribunals at Guantanamo Bav").
} 
the courts of the United States." ${ }^{\text {"26 }}$ Read literally, the panel's holding would permit American officials deliberately to starve the alien detainees, to subject them to forced sterilizations, or to discriminate against them on the basis of their religion or skin color. Yet given the persistent U.S. criticism of Communist Cuba for violating the rights of its prisoners over the past forty years, it would be supremely ironic if the United States now created its own rightsfree zone for alien detainees on that part of Cuba under American jurisdiction. ${ }^{27}$

\section{Undermining Moral Leadership}

The use of military commissions potentially endangers Americans overseas by undermining the U.S. government's ability to protest effectively when other countries use such tribunals. But just as troubling, espousing military commissions undermines U.S. moral leadership abroad when that leadership is needed the most. ${ }^{24}$ The United States regularly takes other countries to task for military proceedings that violate basic civil rights. How, then, can the United States be surprised when its European allies refuse to extradite captured terrorist suspects to U.S. military justice ${ }^{29}$ When the Chinese or Russians try Uighur or Chechen Muslims as terrorists in military courts, U.S. diplomats protest vigorously and the world condemns those tribunals as anti-Muslim. How, then, can the United States object when other countries choose to treat U.S. military commissions the same way?

To win a global war against terrorism, nations that lay claim to moral rectitude and fidelity to the rule of law must not only apply, but also be universally seen to be applying, credible justice. Credible justice for international crimes demands tribunals that are fair and impartial both in fact and in appearance. By their very nature, military tribunals fail this test. Even if, through tinkering, the Defense Department's regulations could ensure that military commissions will operate more fairly in fact, they will never be perceived as fair by those skeptical of their political purpose, namely, the very Muslim nations whose continuing support the United States needs to maintain its durable coalition against terrorism. Ironically, the more the Defense Department tries to address the perceived unfairness of military tribunals by making them more "courtlike"-more transparent, with more procedural protections, more independent decision makers, and more input into their design by the legisiative branch-the more these modifications will eliminate the supposed "practical" advantages of having military tribunals in the first place, yet without dispelling the fatal global perception of unfairness.

\section{THE WAY FORWARD}

Against this background, how should the United States pursue international justice in the months ahead? To ensure that the international community perceives that those convicted

\footnotetext{
${ }^{26}$ Cuban Am. Bar Ass'n v. Christopher, 43 F.3d 1412, 1430 ( 11 th Cir. 1995). The Eleventh Circuit's broad ruling in the Cuban case would effectively treat alien detainees on Guantánamo as human beings without human rights. That ruling conflicted, however, with earlier decisions by the Second Circuit and a Brooklyn federal court involving Haitian refugees on Guantínamo. Haitian Ctrs. Council, Inc. v. McNary, 969 F. 2d 1326 (2d Cir. 1992), vacated as moot on other grounds, 113 S.Ct. 3028 (1993) (finding substantial likelihood that alien detainees on Guantánamo do have due process rights); Haitian Ctrs. Council v. McNary, 823 F.Supp. 1028, 1042 (E.D.N.Y. 1993), vacated by settlement (finding the same on the merits after a full bench trial). I should disclose that I served as counsel of record for both the Haitian and the Cuban refugees in the Guantanamo cases discussed here.

${ }^{27}$ Cf. Harold Hongju Koh, America's Offshore Refugee Camps, 29 RICHmond L. REv. 139, 140-41 (1994) ("[T] he United States government has consistently asserted-and some courts have agreed-that these offshore locations constitute 'rights-free zones,' where [alien detainees] lack any legal rights cognizable under U.S. law and American [lawyers] lack First Amendment rights to communicate with them.").

2* See UN Human Rights Expert Concerned over Military Order Signed by United States President, UN NEWSLETTER (United Nations Information Centre New Delhi) (Nov. 24, 2001), at <htp://www.unic.org.in> (urgent appeal of UN Special Rapporteur for the Independence of the Judiciary Param Cumaraswamy, calling Military Order regrettable for "the wrong signals it sent, not only in the United States, but around the world").

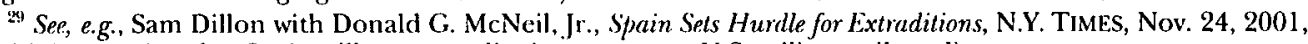
at Al (suggesting that Spain will not extradite its suspects to U.S. military tribunal).
} 
for the September 11 attacks will receive fair and impartial justice, the Lnited States should send suspects only to standing tribunals that have demonstrated their capacity to dispense such justice in the past.

While I have long supported international adjudication, I am skeptical about the international community's ability to overcome existing political obstacles and create a fair international tribunal quickly. ${ }^{36}$ International tribunals make the most sense when there is no functioning municipal court that could fairly and efficiently try the case, as happened in the former Yugoslavia and Rwanda. But even if the United States government were to support such a tribunal here (which it seems unlikely to do), at least two other permanent members of the Security Council-Russia and China-would probably with hold their consent from any body that might pursue trials of Chechen or Uighur rebels whom they have labeled as domestic "terrorists." Recent history shows that building new international tribunals from scratch is slow and expensive and requires arduous negotiations. ${ }^{31}$ Although proponents claim that an international tribunal would be more likely to be viewed as impartial than a U.S. court, it is unclear why an ad hoc tribunal created for the express purpose of trying the September 11 terrorists and their supporters would find greater acceptance throughout the Muslim world than the judgments of a civilian court system that has been in place for more than two centuries. Finally, those who believe that an international tribunal with . Muslim judges would ensure "Muslim buy-in" into the international adjudicatory process should recall that the last United Nations gathering before September 11 was the World Conference Against Racism, in which several Islamic countries sought to use the forum to pursue their political grievances against Israel. ${ }^{32}$ Many of the same countries would doubtless use their diplomatic clout to argue that any UN tribunal to try terrorists should also try Israeli officials who bore no connection to the September 11 attacks, an alternative that potential Western signatories to the tribunal would surely reject. We should not conclude, therefore, that only international tribunals can grant meaningful justice for international crimes. Absent extant, functioning international tribunals, the most credible justice will be delivered by time-tested domestic judicial institutions, such as the United States' Article III courts and courts-martial.

In surveying its justice options, the United States should carefully distinguish between its most pressing concern-redressing and preventing the murder of Americans on American soil-and much broader efforts to support the creation of an enduring post-Taliban system of justice in Afghanistan. International justice demands a clear and simple division of labor: American prosecutors and judges should try crimes committed against Americans on American soil, while experienced UN and international lawyers should address crimes committed against Afghans on Afghan soil.

Cases primarily involving crimes in Afghanistan-whether committed by the Taliban or the Northern Alliance-will be best addressed by rebuilding the judicial svstem of Afghanistan itself, a task that, like the rebuilding of the Sierra Leonean, East Timorese, Bosnian, and Kosovar legal systems, will require substantial and sustained international and L.N input. ${ }^{33}$

\footnotetext{
${ }^{30}$ Some distinguished scholars have argued that such cases should be heard before an international tribunal, preferably one on which both American and Muslim judges sit. See, e.g., Anne-.Harie Slaughter, Al Qaeda Should Be Tried Before the World, N.Y. Times, Nov. 17, 2001, at A23. But see Michael J. Matheson, L.S. Military Commissions: One of Severnl Options, 96 AJIL 354 (2002) (reviewing practical reasons why it remains unlikely that such a tribunal will be created).

${ }^{31}$ For example, the Sierra Leonean tribunal has yet to hear any cases several years after the mass killings there, and a war crimes tribunal for Cambodia has yet to be set up more than twenty-five years after the operative events. Sie Seth Mydans, Khmer Rouge Trials Won't Be Fair, Critics Say, N.Y. TIMEs, Feb. 10, 2002, \$1, at 12.

"2: See Ellis Cose, Silver I.inings from a Summit, NEwSWEt.k, Sept. 17, 2001, at 40.

"3s The precise shape of the Afghan judicial system remains to be determined. I have no objection, for example, to an Afghan tribunal that would combine domestic and international clements, such as the Sierra Leonean tribunal created under UN auspices is designed to do. Whatever happens, United Nations transitional support and involvement will be critically necessary to stabilize the postconflict environment of Afghanistan, to promote the Bonn process of building a representative post-Taliban government, and to address justice, accountability, and truth telling about past human rights abuses by all parties to the Afghan contlict. This part of the judicial problem,
} 
However heinous the offenses of Afghan war criminals against other Afghan citizens may be, they have little to do with the United States, and should not be adjudicated by American courts or courts-martial that have little interest or expertise in the decades-old Afghan conflict. Egregious Afghan violators such as Mullah Omar and his close deputies should be given treatment similar to that given brutal rebel leader Foday Sankoh of Sierra Leone: namely, arrest, humanitarian treatment in custody, permanent exclusion from further governmental activity, no amnesty for war crimes or crimes against humanity, and eventual trial before the emerging Afghan judicial system. ${ }^{34}$ Wherever possible, third-party combatants should be sent back to the country of their nationality to face national punishment, with assurances that their trials will strictly observe international due process standards.

Under this strategy, the U.S. government should send only those cases involving defendants (such as leading Al Qaeda members) who are charged with or suspected of murdering or plotting to murder American citizens on American soil to American civilian courts for criminal trials by seasoned federal prosecutors. Since three Al Qaeda suspects-Zacarias Moussaoui, the "American Taliban" John Walker Lindh, and the "sneaker bomber" Richard Reid-have already been charged before U.S. civilian courts, I see no need to charge any future defendants before untested and suspect military commissions. ${ }^{35}$

In sum, the battle against global terrorism requires credible justice, which military commissions cannot provide. Credible international tribunals can provide credible justice but may be difficult to create under the current political circumstances. That leaves standing civilian courts or courts-martial that operate under preexisting and transparent rules. Sweeping all "unlawful combatants" who have committed "war crimes" into untested, unwise, and legally deficient U.S. military commissions will invite hostile foreign governments reciprocally to "try" and execute captured nonuniformed American personnel before similar tribunals. If the United States wants to show the world its commitment to the very rule of law that the terrorists sought to undermine, it should take this opportunity to demonstrate that American courts can give universal justice.

HAROLD HONGJU KOH*

however, differs little from that faced in Bosnia, East Timor, Kosovo, and Sierra Leone, where the United States similarly supported multilateral military operations that eventually secured a war-torn territory for a new, more democratic government. What makes this military struggle distinctive-and the element that engages U.S. judicial jurisdiction -is that this conflict was triggered by the massive September 11 attacks that killed thousands of American and other civilians on American soil.

${ }^{94}$ While I agree with much of Professor Matheson's sensible analysis, I disagree with his suggestion that persons who commit violations of the law of armed conflict on the battlefield of Afghanistan but have no provable connection to the September 11 attacks should be tried before U.S. military commissions. Instead, I share his alternative view: that " $[\mathrm{e}]$ ven for these persons, the alternative of trial . . by any suitable Afghan tribunals should be considered." Matheson, supra note 30 , at 358.

${ }^{35}$ My colleague Professor Wedgwood speculates that federal court trials of Al Qaeda suspects will jeopardize classified information, limit available evidence, and endanger the security of judges and jurors. Ruth Wedgwood, Al Qaeda, Terrorism, and Military Commissions, 96 AJIL 328 (2002). Having dealt regularly with classified materials and federal trials during stints at both the State and Justice Departments, I find these claims vastly overstated. As one journalist has noted, during twenty-six successful federal prosecutions of jihad supporters over the past eight years, "[n] either the Justice Department nor prosecutors in New York could recall for me a single specific instance when national security was actually compromised during the trials in New York." Keller, supra note 6. Nor is it clear why the potential excludability of some evidence should cripple prosecutors, given the huge volume of evidence that will be amassed in what has regularly been called the largest criminal investigation in history. And although extra security measures should doubtless be taken to ensure the safety of juries, judges, and prosecutors, such measures have been taken routinely in the past, not just in Al Qaeda cases, but also in numerous cases involving organized crime, drug kingpins, and the like. In any event, it now seems clear that the Justice Department has not deemed any of these concerns sufficiently serious to militate against charging Moussaoui, Reid, and Walker in federal court. The Justice Department's indictment practice so far thus casts serious doubt on Professor Wedgwood's claim that "military commissions may be the most practicable course" for trials against Al Qaeda members. Wedgwood, supra, at 330 .

* Of the Board of Editors. 